\title{
Manajemen Layanan Peserta Didik Inklusif di Kota Palangka Raya
}

\author{
Ana Kameloh Dian \\ SMKN-3 Palangka Raya \\ anakamelohdian@ymail.com \\ Desi Erawati \\ IAIN Palangka Raya \\ desi.erawati@iain-palangkaraya.ac.id
}

\begin{abstract}
Service management becomes important to provide a good service to the learners in general, especially on learners inclusive. The focus of the issues examined is how the pattern of service management, especially learners inclusive in SMAN 4 Palangkaraya and how the factors that hinder the management services on learners inclusive, and are there any obstacles in providing services to students at SMAN 4 Palangkaraya inclusive. This study used a qualitative approach, using a sampling technique is purposive sampling. Our research findings show that the management services are basically all the same, but no differences were seen, that there are some things that are found such as recruitment, selection, and placement in inclusive classroom learners in the classroom. Factors inhibiting the service management process inclusive learners there are two internal and external factors. School principals, in this case, seek to follow up on these constraints to appoint one coordinator teachers to become inclusive in the school structure, provide socialization on inclusive education to the school community, as well as monitor and evaluate the implementation of inclusive education in schools.

Keywords : Service management, Learners inclusive
\end{abstract}

\section{A. Pendahuluan}

Undang-Undang No.20 tahun 2003 tentang Sistem Pendidikan Nasional, Pasal 5 ayat 1 s.d 4 menyatakan bahwa: Setiap warga Negara mempunyai hak yang sama untuk memperoleh pendidikan yang bermutu ; warga Negara yang memiliki kelainan fisik, emosional, mental, intelektual, dan/atau sosial berhak memperoleh pendidikan khusus ; warga negara daerah terpencil atau terbelakang serta masyarakat adat yang terpencil berhak memperoleh pendidikan layanan khusus ; Warga Negara yang memiliki potensi kecerdasan dan bakat istimewa berhak memperoleh pendidikan khusus. ${ }^{1}$

Saat ini banyak anak-anak yang tidak dapat menikmati suasana belajar dibangku sekolah karena berbagai sebab, diantaranya, karena alasan ekonomi, jarak sekolah yang jauh, konflik sosial, dan anak-anak yang berkelainan maupun

1 “Undang-Undang No.20 Tahun 2003 ,Pasal 5 Ayat (1 s.d 4)," n.d. 
yang berbakat. Dalam hal ini peran pemerintah sangat penting untuk melindungi dan melayani hak- hak anak dalam menerima pedidikan.

Sejak disahkannya Undang- Undang No 20 tahun 2003 pasal 15 tentang Pendidikan khusus dan pasal 32 tentang pendidikan khusus dan pendidikan layanan khusus serta Peraturan Menteri Pendidikan Nasional Republik Indonesia Nomor 70 tahun 2009 tentang Pendidkan Inklusif bagi peserta didik yang memiliki potensi kecerdasan dan/atau bakat Istimewa, memberikan harapan dan terobosan baru dalam memberikan pelayanan pendidikan bagi anak yang berkebutuhan khusus berupa pelayanan pendidikan inklusif.

Sekolah Luar Biasa / Sekolah berkelainan ( SLB ) sebagai lembaga pendidikan khusus tertua menampung berbagai jenis anak berkelainan, sedangkan Pendidikan Terpadu adalah sekolah biasa yang menampung anak yang berkelainan dengan kurikulum, guru, sarana pengajaran, dan kegiatan belajar mengajar yang sama. Memasuki akhir millennium kedua, visi dan misi kelembagaan sudah cenderung kepada bentuk integrasi. Suatu bentuk dimana anak luar biasa menjadi bagian yang tidak terpisahkan dari masyarakat. ${ }^{2}$

Penyelenggaraan pendidikan Inklusif sesuai dengan ajaran Islam yang dijelaskan dalam Alquran Surah Al-Hujurat 13 sebagai berikut:

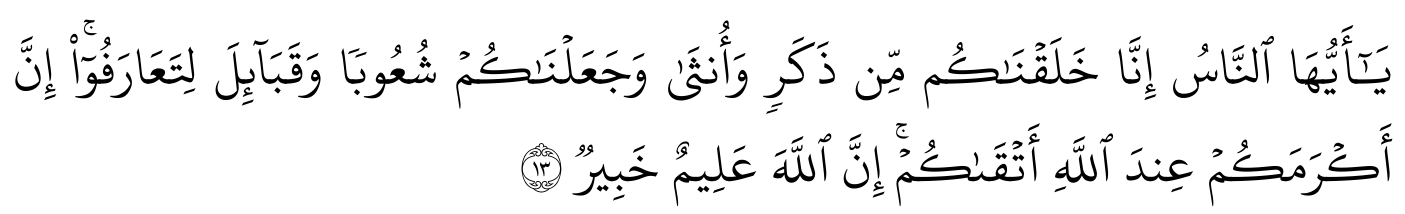

Artinya:"Hai manusia, sesungguhnya Kami menciptakan kamu dari seorang laki-laki dan seorang perempuan dan menjadikan kamu berbangsa-bangsa dan bersuku-suku supaya kamu saling kenal-mengenal. Sesungguhnya orang yang paling mulia diantara kamu disisi Allah ialah orang yang paling takwa diantara kamu. Sesungguhnya Allah Maha Mengetahui lagi Maha Mengenal." .3

Pada pembelajaran inklusif semua orang bagian berharga dalam kebersaman, apapun perbedaan mereka. Semua anak terlepas dari kemampuan maupun ketidakmampuan, jenis kelamin, status sosial ekonomi, suku, latar belakang budaya, bahasa dan agama menyatu dalam komunitas sekolah yang sama.

\footnotetext{
${ }^{2}$ Terry Irenewaty dan Aman, Evaluasi Kebijakan Pendidikan Inklusif Di SMA Muhammadiyah 4 Yogykarta (Yogyakarta, 2007), 3.

3 “Al-Hujurat [49]:13," n.d.
} 
Dalam inklusivitas, semua perbedaan tidak dilihat sebagai problematika, tetapi sebuah tantangan dan pengayaan dalam lingkungan belajar. Mereka jadi siap dan familiar dengan keberagaman, dan merasa nyaman dengan aneka perbedaan. ${ }^{4}$ Usaha untuk memberikan pelayanan pendidikan inklusif telah mulai diberlakukan dikota Palangka Raya, hal ini sebagai salah satu wujud komitmen Pemerintah Kota Palangka Raya dalam melaksanakan amanat Undang-Undang No.20 Tahun 2003 Tentang Pendidikan Nasional pasal 5 dan Peraturan Menteri Pendidikan Nasional Nomor 70 Tahun 2009 tentang Pendidikan inklusif bagi peserta didik yang memiliki kelainan dan memiliki potensi kecerdasan dan/atau bakat istimewa.

Palangka Raya sebagai ibukota Provinsi Kalimantan Tengah berkomitmen untuk menjadikan Palangka Raya sebagai kota pendidikan yang ramah, adil tanpa diskriminasi hal ini berdasarkan Surat Keputusan Walikota Palangka Raya Nomor 328 Tahun 2014 Tentang Kelompok Kerja Pendidikan Inklusif kota Palangka Raya dan Peraturan Walikota Palangka Raya Nomor 26 Tahun 2014 tentang Penyelenggaraan Pendidikan Khusus, Pendidikan Inklusif dan Pusat Sumber di Kota Palangka Raya. Surat Keputusan dan Peraturan Walikota Palangka Raya tersebut harus diimplementasikan dalam pendidikan yang" ramah, adil tanpa dikriminasi" terhadap anak berkebutuhan khusus pada semua sekolah yang ada di Palangka Raya.

Ada beberapa sekolah yang ditunjuk untuk menjadi piloting sekolah inklusif dikota Palangka Raya diantaranya SMAN 8, SMA Muhammadiyah I dan SMAN 4 Palangka Raya, berdasarkan observasi awal Tahun Pelajaran 2015/2016 SMAN 8 masih belum memiliki peserta didik inklusif, SMA Muhamadiyah memiliki satu peserta didik inklusif dengan indikasi lambat belajar, dari sekolah-sekolah tersebut hanya SMAN 4 yang memiliki siswa yang berkebutuhan khusus lebih banyak yaitu 10 orang, berdasarkan pertimbangan tersebut memilih SMAN 4 Palangka Raya sebagai tempat penelitian. Penunjukkan sekolah piloting sebagai penyelenggara

${ }^{4}$ Suyanto dan Mudjito, Masa Depan Pendidikan Inklusif (Jakarta: Kemendikbud, 2014), 11. 
pendidikan inklusif harus memenuhi kriteria berdasarkan Pedoman Umum Penyelenggaraan Pendidikan Inklusif Departemen Pendidikan Nasional meliputi :

"1) Kesiapan sekolah untuk menyelenggarakan program pendidikan inklusif ( kepala sekolah, komite sekolah, guru, peserta didik, dan orang tua); 2) Terdapat anak berkebutuhan khusus di lingkungan sekolah; 3) Tersedia guru pembimbing khusus (GPK) dari PLB (guru tetap sekolah atau guru yang diperbantukan dari lembaga lain); 4) Komitmen terhadap penuntasan wajib belajar; 5) Memiliki jaringan kerjasama dengan lembaga lain yang relevan;

6) Tersedia sarana penunjang yang mudah diakses oleh semua anak; 7) Pihak sekolah telah memperoleh sosialisasi tentang pendidikan inklusif; 8) Sekolah tersebut telah terakreditasi; 9) Memenuhi prosedur adminstrasi yang telah ditentukan." ${ }^{5}$

Berdasarkan kriteria diatas SMAN 4 Palangka Raya yang terletak di Jalan Sisingamangaraja III telah memenuhi kriteria untuk menyelengarakan pendidikan inklusif. Tahun Pelajaran 2015/2016 jumlah siswa di SMAN 4 Palangka Raya 1.134 Orang, siswa inklusif 10 orang meliputi 3 orang lamban belajar, 3 orang tuna daksa, 2 orang low vision ${ }^{6}, 1$ hiperaktif dan 1 orang autisme. ${ }^{7}$

Penyelenggaraan pendidikan inklusif merupakan terobosan baru dalam menciptakan suatu sistem pendidikan moral bagi siswa agar mampu mengkondisikan diri terhadap lingkungan yang komplek dimana keberagaman karakteristik siswa bisa membawa kearah pendidikan baru yang lebih modern. ${ }^{8}$

Tingkatan dalam pendidikan inklusif dapat dibedakan berdasarkan tingkat kelainan peserta didiknya. Hal ini terjadi karena tidak semua sekolah inklusi dapat menerima peserta didik berkebutuhan khusus sepenuh waktu di kelas reguler. Adapun tingkat kelainan peserta didik berkebutuhan khusus adalah:

1. Mild disabilities adalah tingkat kelainan yang ringan dan masih bisa melakukan kegiatan dengan anak- anak seusianya.

\footnotetext{
${ }^{5}$ Luar Biasa Departemen Pendidikan Nasional, Pedoman Umum Penyelenggaraan Pendidikan Inklusif (Jakarta Direktorat Pembinaan Sekolah: Direktorat Pembinaan Sekolah, 2007), 29.

${ }^{6}$ Low Vision Adalah Daya Tajam Penglihatan Yang Sangat Rendah, n.d.

${ }^{7}$ Data Dari Koordinator Inklusif SMAN 4 Palangka Raya, 2016.

${ }^{8}$ Aman, Evaluasi Kebijakan Pendidikan Inklusif Di SMA Muhammadiyah 4 Yogykarta, 6.
} 
2. Moderate disabilities adalah tingkat kelainan sedang, masih bisa melakukan kegiatan dengan bantuan.

3. Severe atau profound disabilities adalah tingkat kelainan berat yang memerlukan pendampingan dan bantuan.

4. Most severe disabilities adalah tingkat kelainan sangat berat yang memerlukan bantuan dan perawatan terus menerus. ${ }^{9}$

Keperluan pengembangan pengajaran pendidikan inklusif dan kemampuan sekolah dalam menerima peserta didik inklusif perlu dilakukan asesment dan identifikasi keunggulan dan hambatan-hambatannya serta kebutuhan khusus peserta didik.

Adapun menjadi pertanyaan dalam penelitian ini adalah pertama, bagaimana pola manajemen layanan peserta didik inklusif di SMA 4 kota Palangka Raya, kedua, bagaimana factor-faktor yang menghambat keberhasilan dalam memberikan layanan peserta didik inklusif di SMA \$ kota Palangka Raya, ketiga, bagaimana upaya pimpinan sekolah dalam menindak lanjuti kendala-kendala dalam memberikan layanan peserta didik inklusif di SMAN 4 Palangka Raya.

\section{B. Kajian Pustaka}

\section{Pengertian Pendidikan Inkusif}

Dalam Peraturan Menteri Pendidikan Nasional (Permendiknas ) No.70 tahun 2009 disebutkan bahwa yang dimaksud dengan pendidikan inklusif adalah sistem penyelenggaraan pendidikan yang memberikan kesempatan kepada semua peserta didik yang memliki kelainan dan memiliki potensi kecerdasan dan/atau bakat istimewa untuk mengikuti pendidikan atau pembelajaran dalam lingkungan pendidikan secara bersama-sama dengan peserta didik pada umumnya. ${ }^{10}$

Pengertian Pendidikan dalam Permendiknas diatas memberikan penjelasan secara rinci mengenai siapa saja yang dapat dimasukkan dalam pendidikan inklusi. Perincian yang diberikan pemerintah ini dapat di pahami sebagai bentuk kebijakan yang sudah disesuaikan dengan kondisi Indonesia, sehingga pemerintah

\footnotetext{
${ }^{9}$ Mudjito, Masa Depan Pendidikan Inklusif, 60.

${ }^{10}$ Permendiknas No.70 Tahun 2009, Tentang Pendidikan Inklusif Bagi Peerta Didik Yang Memiliki Kelainan Dan Memiliki Potensi Kecerdasan Dan/Atau Bakat Istimewa, n.d., 10.
} 
memandang perlu memberikan kesempatan yang sama kepada semua pesera didik dari yang normal, memiliki kelainan, dan memiliki kecerdasan dan/atau bakat istimewa untuk mengikuti pendidikan. Dengan demikian pemerintah mulai mengubah model pendidikan yang selama ini memisah-misahkan peserta didik normal ke dalam sekolah regular, peserta didik dengan kecerdasan luar biasa dan bakat istimewa ke dalam sekolah (baca: kelas) akselerasi, dan peserta didik dengan kelainan ke dalam Sekolah Luar Biasa ( SLB).

Menurut MIF. Baihaqi dan M.Sugiarmin menyatakan bahwa hakikat inklusif adalah mengenai hak setiap siswa atas perkembangan individu, sosial, dan intelektual para siswa harus diberi kesempatan untuk mencapai potensi mereka. Untuk mencapai potensi tersebut, sistem pendidikan harus dirancang dengan memperhitungkan perbedaan-perbedaan yang ada pada diri siswa. Bagi mereka yang memiliki kebutuhan belajar yang luar biasa harus mempunyai akses terhadap pendidikan yang bermutu tinggi dan tepat. ${ }^{11}$

Pendapat Baihaqi dan Sugiarmin diatas, menekankan bahwa setiap siswa berhak untuk mendapatkan pendidikan yang bermutu dan tepat, tanpa membedabedakan perkembangan individu, sosial, dan intelektual, pemerintah sebagai penanggung jawab pendidikan perlu merancang sebuah konsep pendidikan yang mengakomodir perbedaan -perbedaan individu tersebut.

\section{Model pendidikan inklusif}

Pendidikan inklusif memiliki 3 model yaitu :

\section{1). Mainstream}

Mainstream adalah sistem pendidikan yang menempatkan anak- anak berkebutuhan khusus di sekolah- sekolah umum, mengikuti kurikulum akedemis yang berlaku dan guru yang juga tidak harus melakukan adaptasi kurikulum. Mainstream biasanya dilakukan pada anak-anak yang sakit,tetapi sakitnya tidak berdampak pada kemampuan kognitif, seperti epilepsi, asma, dan anak- anak dengan kecacatan sensori. Ini bisa diatasi dengan fasilitas peralatan sepeti alat bantu dan buku braille.

${ }^{11}$ MIF.Baihaqi dan M.Sugiarmin, ,Memahami Dan Membantu Anak ADHD (Bandung: PT.Refika Aditama, 2006), 75-76. 


\section{2). Model Integratif}

Model Integratif adalah menempatkan siswa yang berkebutuhan khusus dalam kelas anak- anak normal, dimana anak- anak berkebutuhan khusus hanya mngikuti pelajaran pelajaran yang dapat mereka ikuti dari gurunya. Sedangkan untuk mata pelajaran akademisnya, anak- anak berkebutuhan khusus itu menerima pelajaran khusus di kelas yang berbeda, dan terpisah dari teman- teman mereka.

\section{3). Model Inklusif}

Model Inklusif adalah menempatkan siswa yang memiliki kelainan dan potensi kecerdasan dan atau bakat istimewa untuk mengikuti pendidikan dan pengajaran di sekolah regular atau umum.Tujannya untuk memberikan kesempatan yang seluas-luasnya dan mewujudkan penyelenggaraan pendidikan yang menghargai keanekaragaman dan tidak dikriminatif. Di lingkungan inklusif inilah, semua peserta didik yang memiliki kelainan fisik, emosional, mental, sosial atau memiliki potensi kecerdasan dan atau bakat istimewa memperoleh pendidikan yang bermutu sesuai dengan kebutuhan dan kemampuannya. ${ }^{12}$

Ketiga model pendidikan inklusif diatas, pendidikan inklusif sangat sesuai untuk dikembangkan di sekolah reguler, hal ini dapat dilihat dari aspek psikologis, akademik, dan sosial.

Aspek psikologis peserta didik di sekolah inklusif memiliki keutamaan dan sisi positif antara lain memiliki kepercayaan diri, bangga pada diri sendiri atas prestasi yang diperolehnya, dan belajar secara mandiri.

Akademik peserta didik inklusif, lebih kreatif dalam pembelajaran, mencoba memahami dan mengaplikasikan pelajaran di sekolah dalam kehidupan sehari-hari, dan lebih dapat meningkatkan kemampuan dalam berkomunikasi .

Segi sosial peserta didik inklusif, dapat bergaul dan membaur dengan peserta didik lainya dan belajar menerima perbedaan dan beradaptasi terhadap perbedaan itu.

${ }^{12}$ Mudjito, Masa Depan Pendidikan Inklusif, 10. 


\section{Sasaran Pendidikan Inklusif}

Sasaran pendidikan inklusif secara umum adalah semua peserta didik yang ada di sekolah regular. Tidak hanya mereka yang sering di sebut sebagai anak berkelainan tetapi juga mereka yang termasuk anak "nomal". Mereka secara keseluruhan harus memahami dan menerima keanekaragaman dan perbedaan individual. Sedangkan secara khusus, sasaran pendidikan inklusif adalah setiap peserta didik yang memiliki kelainan fisik, emosional, mental, sosial, atau memiliki potensi kecerdasan dan/ atau bakat istimewa. Yang dimaksud dengan peserta didik yang memiliki kelainan, terdiri atas :
a) Tunanetra
b) Tunarungu
c) Tunagrahita
d) Tunadaksa
e) Tunalaras
f) kesulitan belajar
g) Autis
h) Tuna Ganda
i) memiliki gangguan motoric
j) Menjadi korban penyalahgunaan narkoba, obat terlarang dan zat adiktif lainnya. ${ }^{13}$

\section{Konsep Manajemen Peserta Didik}

\section{a. Pengertian Manajemen Peserta Didik}

Pengertian dari "management" berasal dari bahasa Inggris "administration" sebagai " the management of executive affairs" (Encyclopedia Amaricana, 1978,p.171). Dengan batasan pengertian seperti ini maka managemen disinonimkan dengan " management" suatu pengertian dalam lingkup yang lebih luas. Dalam pengertian ini, manajemen bukan hanya pengaturan yang terkait dengan pekerjaan tulis menulis, tetapi pengaturan dalam arti luas. ${ }^{14}$

\footnotetext{
${ }^{13}$ Permendiknas No.70 Tahun 2009, Tentang Pendidikan Inklusif Bagi Peerta Didik Yang Memiliki Kelainan Dan Memiliki Potensi Kecerdasan Dan/Atau Bakat Istimewa, 23.

${ }^{14}$ Muhammad Mustari, Manajemen Pendidikan (Jakarta: Rajagrafindo Persada, 2014), 2.
} 
Beberapa pendapat diatas, jelaslah bahwa manajemen adalah suatu aktivitas yang berfungsi untuk mencapai tujuan yang ditetapkan dengan melakukan perencanaan, pengelolaan, pelayanan, pengorganisasian, pengarahan, dan pengaturan dengan mengikutsertakan semua potensi yang ada baik personal maupun material secara efektif dan efesien.

Pengertian Peserta Didik menurut ketentuan umum Undang-Undang RI nomor 20 Tahun 2003 tentang Sistem Pendidikan Nasional adalah anggota masyarakat yang berusaha mengembangkan potensi diri melalui proses pembelajaran yang tersedia pada jalur, jenjang, dan jenis pendidikan tertentu. ${ }^{15}$

Abu Ahmadi berpendapat bahwa peserta didik adalah sosok manusia sebagai individu /pribadi (manusia seutuhnya). Individu diartikan "orang seorang tidak tergantung dari orang lain, dalam arti, benar-benar seorang pribadi yang menentukan diri sendiri dan tidak dipaksa dari luar, mempunyai sifat-sifat dan keinginan sendiri"16

Disimpulkan bahwa Manajemen Peserta Didik adalah layanan yang memusatkan perhatian pada pengaturan, pengawasan, dan layanan siswa di kelas dan di luar kelas seperti: pengenalan, pendaftaran, layanan individual seperti pengembangan keseluruhan kemampuan, minat, kebutuhan sampai ia matang di sekolah. Dari beberapa pengertian dan pendapat diatas dapat diartikan bahwa manajemen peserta didik inklusif adalah memusatkan perhatian pada pengaturan, pengawasan, dan layanan peserta didik inklusif dari peserta didik tersebut masuk sekolah sampai lulus sekolah.

\section{Ruang lingkup Manajemen Peserta Didik}

Ruang lingkup manajemen peserta didik meliputi: ${ }^{17}$

\section{1). Analisis kebutuhan peserta didik}

Langkah pertama dalam kegiatan manajemen peserta didik adalah melakukan analisis kebutuhan yaitu penetapan peserta didik yang dibutuhkan oleh lembaga pendidikan meliputi:

\footnotetext{
15 "Undang-Undang RI No.20 Tahun 2003, Pasal 1 Ayat(4)," n.d.

${ }^{16}$ Sukarti Nasihin dan Sururi, Manajemen Peserta Didik, n.d., 205.

${ }^{17}$ Daryanto dan Mohammad Farid, Konsep Dasar Manajemen Pendidikan Di Sekolah (Yogyakarta: Gava Media, 2013), 8.
} 
a) Merencanakan jumlah peserta didik yang akan diterima dengan pertimbangan daya tampung kelas/jumlah kelas yang tersedia, serta pertimbangan rasio murid dan guru. Secara ideal rasio murid dan guru adalah 1:30.

b) Menyusun program kegiatan kesiswaan yaitu visi dan misi sekolah, minat dan bakat siswa, sarana dan prasarana yang ada, anggaran yang tersedia, dan tenaga kepandidikan yang tersedia.

Analisis kebutuhan peserta didik baru pada pada sekolah penyelenggara pendidikan inklusif seharusnya mengalokasikan paling sedikit satu kursi peserta didik dalam satu rombongan belajar. ${ }^{18}$

Menganalisis kebutuhan dan penetapan peserta didik, sekolah penyelenggara pendidikan inklusif harus menerima peserta didik yang berkebutuhan khusus jika mendaftar di sekolah tersebut dan tidak boleh di tolak, minimal sekolah penyelenggara pendidikan inklusif mengalokasikan paling sedikit satu kursi dalam satu rombongan belajar.

\section{2). Rekruitmen peserta didik}

Rekruitmen peserta didik pada hakeketnya proses pencarian, menentukan peserta didik yang nantinya akan menjadi peserta didik dilembaga yang bersangkutan. Langkah-langkah dalam kegiatan ini adalah :

a) Membentuk panitia penerimaan peserta didik baru yang meliputi dari semua unsur guru, tenaga TU, dan komite sekolah.

b) Pembuatan dan pemasangan pengumuman penerimaan peserta didik baru yang dilakukan secara terbuka. Informasi yang harus ada dalam pengumuman tersebut adalah gambaran singkat lembaga, persyaratan pendaftaran siswa baru (syarat umum dan syarat khusus), cara pendaftaran, waktu pendaftaran, tempat pendaftaran, biaya pendaftaran, waktu dan tempat seleksi, dan pengumuman hasil seleksi.

Rekruitmen peserta didik inklusif tentu berbeda dengan peserta didik normal, untuk rekruitmen peserta didik inklusif adalah dengan mengidentifikasi anak berkelainan, hakekat identifikasi dimaknai sebagai proses penjaringan

${ }^{18}$ Permendiknas No.70 Tahun 2009, Tentang Pendidikan Inklusif Bagi Peerta Didik Yang Memiliki Kelainan Dan Memiliki Potensi Kecerdasan Dan/Atau Bakat Istimewa, pasal 5 ayat 2. 
terhadap anak yang mengalami kelainan/penyimpangan (fisik, intelektual, sosial,emosinal /tingkah laku) dalam rangka pemberian layanan yang sesuai. Hasil dari identifikasi adalah ditemukannya anak-anak berkelainan yang perlu mendapatkan layanan pendidikan khusus melalui program inklusi ${ }^{19}$

\section{3). Seleksi peserta didik}

Seleksi peserta didik merupakan kegiatan pemilihan calon peserta didik menjadi peserta didik di lembaga pendidikan berdasarkan ketentuan yang berlaku. Adapun cara-cara seleksi yang dapat digunakan adalah :

a) Melalui tes atau ujian, yaitu tes psikotest, tes jasmani, tes kesehatan, tes akademik, atau tes keterampilan.

b) Melalui penelusuran bakat kemampuan, biasanya berdasarkan pada prestasi yang diraih oleh calon peserta didik dalam bidang olahraga atau kesenian.

c) Berdasarkan nilai STTB dan nilai UAN.

Seleksi peserta didik inklusif dengan menggunakan proses identifikasi sebagai proses penjaringan untuk melihat kelainan apa yang di alami peserta didik apakah kategori ringan, sedang, atau berat, dengan adanya proses identifikasi memudahkan panitia seleksi untuk menyesuaikan dengan kemampuan sekolah dalam melayani peserta didik tersebut.

\section{4). Orientasi peserta didik}

Orientasi peserta didik baru merupakan kegiatan mengenalkan situasi dan kondisi lembaga pendidikan tempat peserta didik menempuh pendidikan. Lingkungan yang dimaksud adalah lingkungan fisik sekolah dan lingkungan sosial sekolah. Tujuan orientasi tersebut, agar siswa mengerti dan mentaati peraturan yang berlaku di sekolah, peserta didik dapat aktif dalam kegiatan yang diselenggarakan sekolah dan siap menghadapi lingkungan baru secara fisik, mental, dan emosional.

\section{5). Penempatan peserta didik}

Penempatan peserta didik (pembagian kelas) yaitu kegiatan pengelompokkan peserta didik yang dilakukan dengan sistem kelas, pengelompokkan peserta didik bisa dilakukan berdasarkan kesamaan yang ada pada

${ }^{19}$ Ibid., 23. 
peserta didik yaitu jenis kelamin dan umur. Selain itu juga pengelompokan berdasar perbedaan yang ada pada individu peserta didik seperti minat, bakat dan kemampuan. Menurut Hendyat Soetopo, dasar-dasar pengelompokkan peserta didik ada 5 (lima) macam, yaitu:

a) Friendship Grouping

Pengelompokkan peserta didik didasarkan pada kesukaan didalam memilih teman antar peserta didik itu sendiri. Jadi dalam hal ini peserta didik mempunyai kebebasan di dalam memilih teman untuk dijadikan sebagai anggota kelompoknya.

b) Achievement Grouping

Pengelompokkan peserta didik berdasarkan pada prestasi yang dicapai oleh peserta didik. Dalam pengelompokkan ini biasanya diadakan percampuran antara peserta didik yang berprestasi tinggi dengan peserta didik yang berprestasi rendah.

c) Aptitude Grouping

Pengelompokkan didasarkan atas kemampuan dan bakat yang sesuai dengan apa yang dimiliki peserta didik.

d) Attention or interest Grouping

Pengelompokkan peserta didik didasarkan atas perhatian atau minat yang disenangi peserta didik.

e) Intelligence Grouping

Pengelompokkan peserta didik didasarkan atas hasil tes intelegensi peserta didik. $^{20}$

Penempatan peserta didik inklusif dibatasi satu kelas satu peserta didik inklusif $^{21}$, hal ini untuk memudahkan pengelolaan kelas.

\section{6). Pencatatan dan pelaporan}

Pencatatan dan pelaporan peserta didik dimulai sejak peserta didik diterima di sekolah sampai dengan tamat atau meninggalkan sekolah. Tujuan pencatatan tentang kondisi peserta didik dilakukan agar lembaga mampu melakukan

${ }^{20}$ Sururi, Manajemen Peserta Didik, 211.

${ }^{21}$ Ibid., 4.

Jurnal Studi Agama dan Masyarakat

Volume 13, Nomor 2, Desember 2017 
bimbingan yang optimal pada peserta didik. Sedangkan pelaporan dilakukan sebagai bentuk tanggung jawab lembaga dalam perkembangan peserta didik di sebuah lembaga. Adapun pencatatan yang diperlukan untuk mendukung data mengenai siswa adalah :

a. Buku induk siswa,berisi catatan tentang peserta didik yang masuk di sekolah tersebut,pencatatan disertai dengan nomor induk siswa/nomor pokok.

b. Buku klapper, pencatatannya diambil dari buku induk dan penulisannya diurut berdasar abjad.

c. Daftar presensi, digunakan untuk memeriksa kehadiran peserta didik pada kegiatan sekolah.

d. Daftar catatan pribadi peserta didik berisi data setiap peserta didik beserta riwayat keluarga, pendidikan, dan data psikologis.

\section{Evaluasi kegiatan peserta didik}

Menurut Wand dan Brown(dalam Syaiful Bahri Djamarah dan Aswan Zain,2002;57), evaluasi adalah suatu tindakan atau suatu proses untuk menentukan nilai dari sesuatu.Evaluasi hasil belajar peserta didik berarti kegiatan menilai proses dan hasil belajar siswa baik yang berupa kegiatan kurikuler, kokulikuler, maupun ektrakulikuler.

Penilaian dalam penyelenggara sekolah inklusif mengacu pada model pengembangan kurikulum yang dipergunakan, yaitu : ${ }^{22}$

a. Penilaian hasil belajar bagi peserta didik inklusif mengacu pada kurikulum tingkat satuan pendidikan yang bersangkutan.

b. Peserta didik yang mengikuti pembelajaran berdasarkan kurikulum yang dikembangkan sesuai dengan standar nasional pendidikan atau diatas standar nasional pendidikan wajib mengikuti ujian nasional.

c. Peserta didik yang memiliki kelainan dan mengikuti pembelajaran berdasarkan kurikulum yang dikembangkan dibawah standar nasional pendidikan mengikuti ujian yang diselenggarakan oleh satuan pendidikan yang bersangkutan.

${ }^{22}$ Permendiknas No.70 Tahun 2009, Tentang Pendidikan Inklusif Bagi Peerta Didik Yang Memiliki Kelainan Dan Memiliki Potensi Kecerdasan Dan/Atau Bakat Istimewa, 30. 
d. Peserta didik yang menyelesaikan pendidikan dan lulus ujian sesuai dengan standar nasional pendidikan mendapatkan ijazah yang blangkonya dikeluarkan oleh Pemerintah.

e. Peserta didik yang memiliki kelainan yang menyelesaikan pendidikan berdasarkan kurikulum yang dikembangkan oleh satuan pendidikan dibawah standar nasional pendidikan mendapatkan surat tanda tamat belajar yang blangkonya dikeluarkan oleh satuan pendidikan yang bersangkutan,

f. Peserta didik yang memperleh surat tanda tamat belajar dapat melanjutkan pendidikan pada tingkat atau jenjang yang lebih tinggi pada satuan pendidikan inklusif atau satuan pendidikan khusus.

Berdasarkan penjelasan diatas pemerintah mengakomodasi kebutuhan dan kemampuan peserta didik berdasarkan bakat, minat, dan potensinya sehingga tidak merugikan peserta didik. Jika peserta didik mengikuti pembelajaran sesuai standar nasional pendidikan wajib mengikuti ujian nasional dan mendapatkan ijazah yang blangkonya dikeluarkan pemerintah, tapi jika peserta didik mengikuti pembelajaran pada satuan pendidikan dan mengikuti ujian di bawah standar nasional pendidikan maka akan mendapatkan ijazah yang blangkonya dikeluarkan oleh satuan pendidikan yang bersangkutan, walau demikian peserta didik masih bisa melenjutkan pendidikan ke jenjang yang lebih tinggi pada satuan pendidikan yang menyelenggarakan pendidikan inklusif.

\section{Metode Penelitian}

Metode dalam menggali data di lapangan adalah menggunakan pendekatan penelitian kualitatif deskriptif, hal ini untuk melihat secara langsung kondisi di lapangan di sekolah yang dituju, sehingga bisa melihat langsung dengan kondisi alamiah.

Sebagai pusat penelitian disini adalah SMAN 4 kota Palangka Raya, informannya adalah Informan atau nara sumber yang terdiri dari, kepala sekolah, wali kelas, guru bimbingan konseling, koordinator program inklusif di sekolah, guru, dan para siswa. Tempat dan aktivitas pendidikan inklusif d SMAN 4 Palangka Raya. Teks yang berupa arsip dan dokumen resmi mengenai program 
pendidikan dan pengajaran, kurikulum, foto-foto, dan catatan -catatan lain yang relevan.

\section{Pembahasan}

\section{Pola Manajemen Layanan Peserta Didik Inklusif di SMAN 4 Palangka Raya}

Pola Manajemen peserta didik inklusif di SMAN 4 Palangka Raya sama dengan manajemen peserta didik reguler, artinya manajemen layanan peserta didik normal menyatu dengan manajemen layanan peserta didik inklusif yaitu dari analisis kebutuhan peserta didik, rekruitmen peserta didik,seleksi peserta didik, orientasi peserta didik, penempatan peserta didik, pembinaan dan pengembangan peserta didik, dan evaluasi peserta didik. Sebagai sekolah penyelenggara pendidikan inklusif maka SMAN 4 Palangka Raya harus menerima peserta didik berkebutuhan khusus hal ini sesuai dengan Petunjuk Teknis Penerimaan Peserta Didik Baru (PPDB) bagi SMA dan SMK Kota Palangka Raya Tahun Pelajaran 2015/2016. Ruang lingkup manajemen peserta didik inklusif di SMAN 4 Palangka Raya meliputi :

a) Analis kebutuhan peserta didik

Analis kebutuhan peserta didik inklusif di SMAN 4 Palangka Raya tidak jauh berbeda dengan analis sekolah reguler pada umumnya, yaitu diawali dengan merencanakan jumlah peserta didik yang akan diterima dan menyusun program kegiatan kesiswaan. Hal ini sesuai pendapat Daryanto dan Mohammad Farid ${ }^{23}$ yang menyatakan bahwa langkah pertama dalam kegiatan manajemen peserta didik adalah melakukan analis kebutuhan yaitu penetapan peserta didik yang dibutuhkan oleh lembaga pendidikan dengan pertimbangan daya tampung kelas/jumlah kelas yang tersedia, serta pertimbangan rasio murid dan guru. Secara ideal rasio murid dan guru adalah 1:30 dan menyusun program kegiatan kesiswaan yaitu visi dan misi sekolah, minat dan bakat siswa, sarana dan prasarana yang ada, anggaran yang tersedia, dan tenaga kependidikan yang tersedia. Analisis peserta didik baru pada sekolah penyelenggara pendidikan inklusif seharusnya mengalokasikan paling

${ }^{23}$ Farid, Konsep Dasar Manajemen Pendidikan Di Sekolah, 55. 
sedikit satu kursi peserta didik dalam satu rombongan belajar. ${ }^{24}$ Berdasarkan data yang diperoleh dilapangan jumlah peserta didik yang diterima di SMAN 4 Palangka Raya Tahun Pelajaran 2015/2016 menerima sebanyak 12 ruang kelas dengan jumlah kuota total 409 peserta didik baru (normal maupun berkebutuhan khusus) masing -masing 34 dalam satu kelas. Hal ini tidak ideal karena rasio murid dan guru yang ideal 1:30 Sedangkan analisis kebutuhan peserta didik inklusif berdasarkan Permendiknas Nomor 70 tahun 2009 pasal 5 ayat 2 seharusnya dapat menerima peserta didik inklusif 12 orang ternyata peserta didik inklusif yang diterima untuk tahun pelajaran 2015/2016 hanya tiga orang berarti kuota yang diberikan pihak sekolah untuk peserta didik inklusif tidak terpenuhi.

b) Rekruitmen Peserta Didik

Proses rekruitmen peserta didik baru di SMAN 4 Palangaka Raya baik reguler maupun inklusif dilaksanakan secara serentak dengan sekolah sekolah negeri lain, hal ini sesuai dengan jadwal yang telah ditentukan berdasarkan Petunjuk Teknis Penerimaan Peserta Didik baru (PPDB) bagi SMA/SMK Kota Palangka Raya Tahun Pelajaran 2015/2016, tepatnya awal tahun ajaran baru sekitar bulan Juni. Perekruitmen peserta didik baru di SMAN 4 Palangka Raya diawali dengan Pembentukan Panitia Peserta Didik Baru yang melibatkan kepala sekolah, guru, tata usaha dan komite sekolah dan untuk menarik minat calon peserta didik pembuatan dan pemasangan pengumuman penerimaan peserta didik yang dilakukan secara terbuka. Hal ini sesuai dengan Daryanto dan Mohammad Farid ${ }^{25}$ yaitu langkah-langkah dalam kegiatan rekruitmen peserta didik adalah (a) membentuk panitia penerimaan peserta didik baru yang meliputi dari semua unsur guru, tenaga TU, dan Komite Sekolah (b) pembuatan dan pemasangan pengumuman penerimaan peserta didik baru yang dilakukan secara terbuka. Namun untuk perekruitmen peserta didik baru inklusif dilakukan identifikasi dan asesmen bekerja sama dengan tenaga ahli dari rumah sakit jiwa kalawa atei untuk mengetahui jenis-jenis kelainan atau hambatan yang dialami peserta didik sehingga

\footnotetext{
${ }^{24}$ Permendiknas No.70 Tahun 2009, Tentang Pendidikan Inklusif Bagi Peerta Didik Yang Memiliki Kelainan Dan Memiliki Potensi Kecerdasan Dan/Atau Bakat Istimewa, 4.

${ }^{25}$ Farid, Konsep Dasar Manajemen Pendidikan Di Sekolah, 55.
} 
pihak sekolah dapat memberi layanan yang diperlukan. Hal ini sesuai dengan Permendiknas Nomor 70 Tahun 2009 yang menyatakan untuk rekruitmen peserta didik inklusif adalah dengan mengidentifikasi anak berkelainan .

c) Seleksi Peserta Didik

Seleksi peserta didik baru di SMAN 4 Palangka Raya dilakukan oleh Panitia Penerimaan Peserta Didik Baru. Seleksi peserta didik dilakukan melalui lima cara seleksi yaitu tes tertulis yang mana nilai hasil tertulis diperoleh dengan komposisi $75 \%$ hasil tes tertulis dan 25\% nilai akhir nasional, jalur seleksi siswa tidak mampu, jalur prestasi baik prestasi akademik, olahraga dan seni, jalur seleksi siswa dari luar Palangka Raya, dan jalur inklusif. Cara-cara seleksi tersebut ada yang sesuai dan ada yang tidak sesuai dengan pendapat Daryanto dan Mohammad Farid $^{26}$ yang menyatakan cara-cara seleksi yang digunakan adalah, (a) melalui tes atau ujian yaitu tes psikotes, tes jasmani, tes kesehatan,tes akademik, atau tes keterampilan.(2) melalui penelusuran bakat kemampuan, biasanya berdasarkan pada prestasi yang diraih oleh calon peserta didik dalam bidang olahraga dan seni.(3) berdasarkan nilai STTB dan nilai UAN, tidak sesuainya cara seleksi peserta didik menurut pendapat Daryanto dan Mohammad Farid berdasarkan kebijakan Dinas pendidikan Kota Palangka Raya yang ingin peserta didik tidak mampu dan luar daerah mendapatkan kesempatan yang sama dalam menerima layanan pendidikan. Seleksi peserta didik inklusif sudah sesuai dengan Permendiknas Nomor 70 Tahun 2009 yang menyatakan istilah identifikasi dimaknai sebagai proses penjaringan untuk melihat kelainan apa yang dialami peserta didik dalam rangka pemberian layanan pendidikan yang sesuai. Hasil dari identifikasi ditemukannya anak-anak yang berkelainan yang perlu mendapatkan layanan pendidikan khusus melalui program inklusi. ${ }^{27}$

d) Orientasi Peserta Didik

Orientasi peserta didik baru di SMAN 4 Palangka Raya diikuti oleh semua peserta didik inklusif maupun normal, tidak ada perbedaan dalam pelaksanaanya.

\footnotetext{
26 Ibid.

${ }^{27}$ Permendiknas No.70 Tahun 2009, Tentang Pendidikan Inklusif Bagi Peerta Didik Yang Memiliki Kelainan Dan Memiliki Potensi Kecerdasan Dan/Atau Bakat Istimewa, 23.
} 
Pelaksanaan orientasi di SMAN 4 Palangka Raya meliputi pengenalan situasi kondisi lingkungan sekolah, pengenalan tata tertib sekolah dan penyesuaian dalam menghadapi proses pembelajaran di sekolah hal ini sesuai dengan pendapat Sukarti Nasihin dan Sururi $^{28}$ Orientasi peserta didik inklusif disesuaikan dengan kemampuannya dalam mengikuti masa orientasi terutama jika berhubungan dengan latihan fisik, hal ini sesuai dengan prinsip-prinsip penyelenggaraan pendidikan inklusif yaitu prinsip kebutuhan individual, setiap anak memiliki kemampuan dan kebutuhan yang berbeda-beda, oleh karena itu pendidikan harus diusahakan untuk menyesuaikan dengan kondisi anak. ${ }^{29}$

e) Penempatan Peserta Didik

Penempatan peserta didik inklusif (pembagian kelas) mengacu pada Permendiknas nomor 70 pasal 5 ayat $2^{30}$ mengalokasikan satu kursi dalam satu rombongan belajar, penempatan peserta didik dikelas juga berdasarkan nilai ujian atau STTB yang diperoleh sebelumnya hal ini sesuai dengan pendapat Muhammad Mustari $^{31}$, Daryanto dan Mohammad Farid ${ }^{32}$. Posisi tempat duduk peserta didik inklusif dikelas ditempatkan didepan hal ini untuk mempermudah guru dalam memberikan pelayanan pendidikan.

f) Pencatatan dan Pelaporan Peserta didik

Pencatatan dan pelaporan peserta didik inklusif di SMAN 4 Palangka Raya sama seperti peserta didik normal yaitu ada buku induk, buku klapper,daftar presensi, daftar mutasi , buku catatan pribadi peserta didik, daftar nilai, buku legger , dan buku raport, hal ini sudah sesuai dengan pendapat Sukarti Nasihin dan Sururi $^{33}$. Pencatatan dan pelaporan peserta didik sangat bermanfaat untuk mengetahui data-data peserta didik secara lengkap dimulai sejak diterima disekolah sampai mereka tamat atau meninggalkan sekolah. Pencatatan dan pelaporan yang telah dilakukan SMAN 4 Palangka Raya Seharusnya membedakan pencatatan dan

\footnotetext{
${ }^{28}$ Sururi, Manajemen Peserta Didik, 210.

${ }^{29}$ Permendiknas No.70 Tahun 2009, Tentang Pendidikan Inklusif Bagi Peerta Didik Yang Memiliki Kelainan Dan Memiliki Potensi Kecerdasan Dan/Atau Bakat Istimewa, 19.

${ }^{30}$ Ibid., 4.

${ }^{31}$ Mustari, Manajemen Pendidikan, 114.

${ }^{32}$ Farid, Konsep Dasar Manajemen Pendidikan Di Sekolah, 56.

${ }^{33}$ Sururi, Manajemen Peserta Didik, 212-14.
} 
pelaporan untuk peserta didik inklusif untuk memudahkan memantau perkembangan peserta didik, terutama untuk melihat perkembangan catatan kepribadiannya karena walau bagaimanapun catatan kepribadian peserta didik normal dan inklusif berbeda.

g) Pembinaan dan pengembangan Peserta Didik

Pembinaan dan pengembangan peserta didik meliputi kurikuler dan ekstra kurikuler dan layanan khusus yang menunjang manajemen peserta didik meliputi bimbingan konseling, layanan perpustakaan, layanan kantin, dan layanan kesehatan. Pembinaan dan pengembangan serta layanan khusus yang diberikan sekolah kepada peserta didik di SMAN 4 Palangka Raya sama tidak ada perbedaan dalam melayani kebutuhan peserta didik normal dan peserta didik inklusif hal ini sudah sesuai dengan Permendiknas Nomor 70 tahun 2009 pasal 2 bagian (b) yang menyatakan bahwa " mewujudkan penyelenggaraan pendidikan yang menghargai keanekaragaman, dan tidak diskriminatif bagi semua peserta didik" ${ }^{34}$. Berdasarkan Peraturan Menteri Pendidikan Nasional Nomor 70 tahun 2009 pasal 2 bagian (b) diatas, pembinaan dan pelayanan sekolah kepada peserta didik inklusif harus menghargai keanekaragaman dan tidak diskriminatif, jika bentuk pembinaan dan layanannya berbeda tentu terjadi diskriminasi dalam memberikan pelayanan dan hal ini bertentangan dengan prinsip-prinsip penyelenggaraan pendidikan inklusif. Menurut penulis pembinaan dalam kurikuler (proses pembelajaran) harus sesuai dengan potensi dan kebutuhan peserta didik, mengingat peserta didik berbeda dengan peserta didik normal lainya begitu juga dalam memberikan layanan bimbingan konseling untuk peserta didik inklusif harus lebih intensif dibandingkan peserta didik normal lainnya, terutama dalam hal pemberian motivasi dan peningkatan rasa percayan diri, dan juga layanan perpustakaan harus lebih banyak menambah koleksi buku-bukunya agar peserta didik lebih bergairah mengunjungi perpustakaan dan menambah koleksi-koleksi untuk peserta didik inklusif.

${ }^{34}$ Permendiknas No.70 Tahun 2009, Tentang Pendidikan Inklusif Bagi Peerta Didik Yang Memiliki Kelainan Dan Memiliki Potensi Kecerdasan Dan/Atau Bakat Istimewa, 3. 
h) Evaluasi Kegiatan Peserta Didik

Evaluasi atau kegiatan penilaian peserta didik adalah suatu proses untuk menentukan nilai dari sesuatu. Evaluasi peserta didik sangat penting baik bagi peserta didik itu sendiri atau buat guru dan orang tua untuk melihat perkembangan /kemajuan peserta didik dalam mengikuti proses belajar mengajar. Evaluasi untuk peserta didik inklusif sama dengan peserta didik normal lainnya. Hal ini sesuai dengan Pedoman Umum Penyelenggaraan Pendidikan Inklusif yang menyebutkan :" Penilaian dalam setting inklusif mengacu pada model pengembangan kurikulum yang dipergunakan, yaitu : apabila menggunakan model kurikulum reguler penuh, maka penilaiannya menggunakan sistem penilaian yang berlaku pada sekolah reguler. ${ }^{35}$

\section{Faktor faktor yang menghambat proses manajemen layanan peserta didik inklusif di SMAN 4 Palangka Raya}

Penyelenggaraan pendidikan inklusif banyak sekali faktor-faktor yang menghambat proses manajemen layanan peserta didik inklusif di SMAN 4 Palangka Raya yaitu faktor internal dan eksternal, faktor internal adalah faktor yang berasal dari dalam lembaga pendidikan (sekolah),yaitu guru-guru di SMAN 4 Palangka Raya belum semuanya mengikuti penataran atau workshop tentang prosedur mengajar atau memberikan pelayanan kepada peserta didik inklusif. Peserta didik inklusif adalah peserta didik yang memiliki kelainan fisik, emosional, mental, sosial atau memiliki potensi kecerdasan dan/atau bakat istimewa, karena berbagai hambatan yang dialami peserta didik inklusif maka seharusnya guru-guru yang sekolahnya ditunjuk menjadi penyelenggara pendidikan inklusif mendapatkan penataran, pelatihan atau workshop bagaimana seharusnya melayani peserta didik inklusif karena bagaimanapun peserta didik berkelainan sangat bervariasi mulai dari yang sifatnya ringan, sedang, sampai berat, dan hal ini tentu membutuhkan strategi pembelajaran yang tepat, baik dari sisi kurikulum dan evaluasi. Hambatan lain yang dialami adalah belum ada tenaga ahli yang menangani peserta didik inklusif di sekolah, dan hal ini menjadi kendala karena menangani peserta didik

${ }^{35}$ Nasional, Pedoman Umum Penyelenggaraan Pendidikan Inklusif, 24. 
inklusif berbeda dengan peserta didik normal. Hambatan-hambatan yang dialami SMAN 4 Palangka Raya sebagai penyelenggara pendidikan inklusif tidak jauh berbeda dengan hambatan-hambatan yang dialami sekolah lain yang menyelenggarakan pendidikan inklusif (Hasil diskusi dengan guru dan kepala sekolah penyelenggara pendidikan inklusif peserta pelatihan di Yogyakarta tahun 2009) antara lain:

(1) masih ada kesulitan menyelaraskan antara standar layanan persekolahan reguler yang selama ini berjalan dan variasi kebutuhan belajar ABK ...; (4) belum ada sistem evaluasi hasil belajar (baik formatif dan sumatif) yang tepat sesuai kebutuhan ABK...; (6) belum semua guru reguler memiliki kompetensi memberikan layanan ABK dan masih minimnya guru khusus di sekolah inklusif. ${ }^{36}$

Adapun hambatan eksternal yang dialami SMAN 4 Palangka Raya dalam menyelenggarakan pendidikan inklusif adalah dari orang tua peserta didik inklusif yang menyerahkan sepenuhnya tanggung jawab pendidikan kepada sekolah, hal ini tidak boleh terjadi karena pendidikan menjadi tanggung jawab bersama antara sekolah, orangtua dan masyarakat. Dalam implementasi pengelolaan pendidikan inklusif, salah satu hal yang harus diperhatikan penyelenggara pendidikan inklusif adalah guru dituntut melibatkan orangtua secara bermakna dalam proses pendidikan. ${ }^{37}$

Pihak sekolah sebagai penyelenggara pendidikan inklusif diharapkan pro aktif melibatkan orang tua peserta didik inklusif atau yang peduli pendidikan inklusif untuk bekerja sama dengan sekolah mendukung pelaksanan inklusif di sekolah.

Hambatan-hambatan yang dialami SMAN 4 Palangka Raya dalam menyelenggarakan pendidikan inklusif perlu ditindak lanjuti dan dicari jalan keluarnya agar tujuan dari penyelenggaraan pendidikan inklusif dapat terlaksana dengan baik.

\footnotetext{
${ }^{36}$ Ishartiwi, "Implementasi Pendidikan Inklusif Bagi Anak Berkebutuhan Khusus Dalam Sistem Persekolahan Nasional," Jurnal Pendidikan Khusus 06, no. 02 (2010): 2.

${ }^{37}$ Permendiknas No.70 Tahun 2009, Tentang Pendidikan Inklusif Bagi Peerta Didik Yang Memiliki Kelainan Dan Memiliki Potensi Kecerdasan Dan/Atau Bakat Istimewa, 22.
} 


\section{Upaya Pimpinan Sekolah dalam menindak lanjuti kendala-kendala dalam memberikan layanan peserta didik inklusif di SMAN 4 Palangka Raya}

Adanya hambatan-hambatan dalam proses manajemen layanan peserta didik inklusif di SMAN 4 Palangka Raya perlu ditindak lanjuti oleh pimpinan sekolah sebagai penanggung jawab penyelenggara pendidikan inklusif. Selama ini hal yang telah dilakukan pimpinan sekolah dalam menindak lanjuti kendalakendala dalam memberikan layanan kepada peserta didik inklusif adalah dengan mengangkat atau menugaskan salah satu guru menjadi koordinator inklusif di sekolah dan memasukkan koordinator inklusif dalam struktur sekolah. Apa yang telah dilakukan pimpinan sekolah sudah tepat karena untuk pelaksanaan manajemen inklusif perlu merubah struktur sekolah dan mengangkat guru sebagai koordinator inklusif untuk memudahkan koordinasi dan peningkatan mutu pendidikan inklusif di sekolah, ${ }^{38}$ upaya lain yang dilakukan adalah memberikan sosialisasi tentang pendidikan inklusif kepada warga sekolah dan melakukan monitoring dan evaluasi terhadap penyelenggaraan pendidikan inklusif di sekolah. Apa yang telah dilakukan pimpinan sekolah sudah tepat dan sesuai dengan strategi pembudayaan pendidikan inklusif yaitu pada tahapan proses pembudayaan inklusif dimulai dari tahap pengenalan, tahap pengembangan dan tahap pembudayaan. ${ }^{39}$ Tahap pengenalan adalah suatu tahap atau kondisi di mana warga sekolah memahami pendidikan inklusif, dari data dilapangan semua warga sekolah dari kepala sekolah, guru, penjaga kantin, dan siswa sudah tahu bahwa sekolah mereka menerima anak berkebutuhan khusus (inklusif) dan hal ini merupakan suatu hal yang luar biasa bagi sekolah tersebut karena ada sebagian sekolah yang menolak siswa berkebutuhan khusus dengan alasan menurunkan reputasi sekolah dan bukan sekolah luar biasa. Pelaksanaan manajemen layanan peserta didik inklusif di SMAN 4 Palangka Raya walaupun banyak hambatan dan kendala tapi berhasil dilaksanakan, dimana semua anak mempunyai hak yang sama untuk memperoleh

\footnotetext{
38 Ibid., 32.

${ }^{39}$ Kemendikbud Direktorat Pembinaan Pendidikan Khusus dan Layanan Khusus, Strategi Umum Pembudayaan Pendidikan Inklusif Di Indonesia (Jakarta, 2014), 25-27.
} 
pendidikan yang bermutu dan tidak didiskriminasikan, hal ini sesuai dengan pandangan Islam terdapat dalam surah Abasa ayat 1- 4:

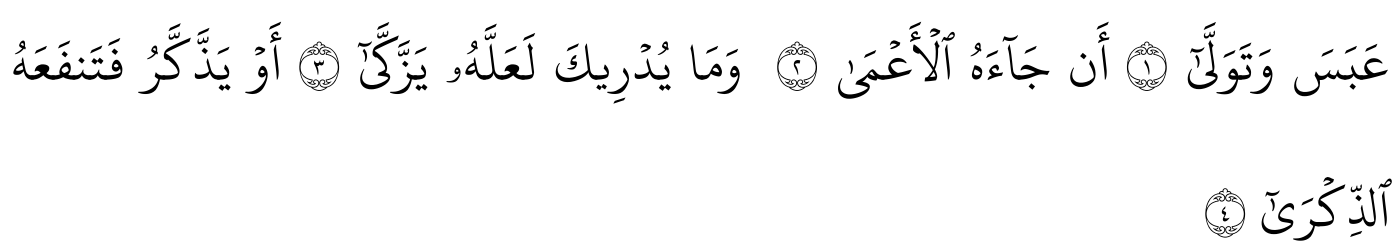

Artinya:'Dia (Muhammad) bermuka masam dan berpaling. karena telah datang seorang buta kepadanya. Tahukah kamu barangkali ia ingin membersihkan dirinya (dari dosa). Atau dia (ingin) mendapatkan pengajaran, lalu pengajaran itu memberi manfaat kepadanya." 40

\section{E. Kesimpulan}

Pertama, Pola manajemen layanan peserta didik inklusif sama dengan pola manajemen peserta didik reguler lainnya, meliputi analisis kebutuhan peserta didik, dalam menganalisis kebutuhan peserta didik inklusif SMAN 4 Palangka Raya menerima peserta didik inklusif tanpa pembatasan jumlah peserta didik, minimal satu rombongan belajar terdapat satu peserta didik inklusif, ternyata kuota yang diberikan pihak sekolah untuk peserta didik inklusif tahun pelajaran 2015/2016 tidak terpenuhi, dalam hal rekruitmen peserta didik, rekruitmen peserta didik inklusif tidak melalui tes tetapi melalui identifikasi anak berkelainan bekerja sama dengan tenaga ahli dari rumah sakit jiwa kalawa atei, seleksi peserta didik, seleksi peserta didik inklusif tidak ada persyaratan khusus tetapi melalui asesment dan identifikasi atau surat keterangan anak berkebutuhan khusus dari sekolah asal, orientasi peserta didik, orientasi peserta didik inklusif sama dengan peserta didik normal lainnya kecuali untuk latihan fisik disesuaikan dengan kemampuan peserta didik inklusif, penempatan peserta didik, penempatan peserta didik inklusif dikelas berada paling depan hal ini untuk mempermudah guru dalam memantau perkembangan peserta didik inklusif, pencatatan dan pelaporan, pencatatan dan pelaporan peserta didik inklusif sama dengan peserta didik normal lainnya, seharusnya pihak sekolah membedakan pencatatan dan pelaporan untuk peserta didik inklusif hal ini untuk mempermudah memantau perkembangan peserta didik

40 “Abasa [80]:1-4," n.d. 
inklusif, pembinaan dan pengembangan peserta didik meliputi kegiatan kurikuler dan ektra kurikuler dan layanan khusus diantaranya layanan bimbingan konseling, layanan perpustakaan, dan layanan kantin, sama dengan peserta didik normal tidak ada perlakuan khusus, seharusnya peserta didik inklusif mendapatkan layanan yang lebih intensif dibandingkan dengan peserta didik normal lainnya terutama layanan bimbingan konseling agar peserta didik lebih percaya diri dan memiliki motivasi belajar yang baik dalam mengikuti pelajaran, evaluasi kegiatan peserta didik, dalam hal evaluasi kegiatan peserta didik inklusif sama dengan peserta didik normal lainnya. Kedua, faktor yang menghambat proses manajemen layanan peserta didik inklusif di SMAN 4 Palangka Raya meliputi faktor internal yaitu para guru di SMAN 4 Palangka Raya belum semuanya mengukuti penataran atau workshop tentang prosedur mengajar atau memberikan pelayanan kepada peserta didik inklusif, dan belum adanya guru pembimbing khusus untuk peserta didik inklusif, faktor eksternal, adalah dimana orang tua menyerahkan anak sepenuhnya kepada sekolah dan tidak bertanggung jawab lagi terhadap perkembangan pendidikannya. Ketiga, upaya Pimpinan Sekolah dalam menindak lanjuti kendala-kendala dalam memberikan layanan peserta didik inklusif di SMAN 4 Palangka Raya mengangkat guru menjadi koordinator inklusif dan memasukkan koordinator inklusif dalam struktur sekolah sehingga memudahkan koordinasi dengan pihak lain dan menyelenggarakan sosialisasi tentang pendidikan inklusif kepada warga sekolah.

\section{Daftar Pustaka}

“Abasa [80]:1-4," n.d.

"Al-Hujurat [49]:13," n.d.

Aman, Terry Irenewaty dan. Evaluasi Kebijakan Pendidikan Inklusif Di SMA Muhammadiyah 4 Yogykarta. Yogyakarta, 2007.

Data Dari Koordinator Inklusif SMAN 4 Palangka Raya, 2016.

Farid, Daryanto dan Mohammad. Konsep Dasar Manajemen Pendidikan Di Sekolah. Yogyakarta: Gava Media, 2013.

Ishartiwi. "Implementasi Pendidikan Inklusif Bagi Anak Berkebutuhan Khusus Dalam Sistem Persekolahan Nasional.” Jurnal Pendidikan Khusus 06, no. 02 (2010).

Khusus, Kemendikbud Direktorat Pembinaan Pendidikan Khusus dan Layanan. Strategi Umum Pembudayaan Pendidikan Inklusif Di Indonesia. Jakarta, 2014. 
Low Vision Adalah Daya Tajam Penglihatan Yang Sangat Rendah, n.d.

M.Sugiarmin, MIF.Baihaqi dan. ,Memahami Dan Membantu Anak ADHD. Bandung: PT.Refika Aditama, 2006.

Mudjito, Suyanto dan. Masa Depan Pendidikan Inklusif. Jakarta: Kemendikbud, 2014.

Mustari, Muhammad. Manajemen Pendidikan. Jakarta: Rajagrafindo Persada, 2014.

Nasional, Luar Biasa Departemen Pendidikan. Pedoman Umum Penyelenggaraan Pendidikan Inklusif. Jakarta Direktorat Pembinaan Sekolah: Direktorat Pembinaan Sekolah, 2007.

Permendiknas No.70 Tahun 2009, Tentang Pendidikan Inklusif Bagi Peerta Didik Yang Memiliki Kelainan Dan Memiliki Potensi Kecerdasan Dan/Atau Bakat Istimewa, n.d.

Sururi, Sukarti Nasihin dan. Manajemen Peserta Didik, n.d.

"Undang-Undang No.20 Tahun 2003 ,Pasal 5 Ayat (1 s.d 4)," n.d.

“Undang-Undang RI No.20 Tahun 2003, Pasal 1 Ayat(4)," n.d. 